\title{
Lactate dehydrogenase elevations is associated with severity of COVID-19: a meta-analysis
}

\author{
Xiao-Yun Chen ${ }^{1}$, Ming-Yao Huang ${ }^{2}$, Zheng-wei Xiao ${ }^{3}$, Sheng Yang ${ }^{1 *}$ and Xiang-Qi Chen ${ }^{1 *}$
}

Keywords: COVID-19, Lactate dehydrogenase, Severe disease

\section{Dear Editor,}

The coronavirus disease 2019 (COVID-19) has become one of the most serious pandemics of the recent times. It is crucial and necessary to identify laboratory markers which could provide predictions for the severity as well as the prognosis of the disease in order to guarantee proper clinical care for the patients. Therefore, the aim of this meta-analysis is to explore the unclear association of lactate dehydrogenase $(\mathrm{LDH})$ elevations and the severity of COVID-19.

We gained access to relevant literature by searching PubMed, EMBASE, and The Cochrane Library through June 3, 2020. We used the following terms: "Lactate Dehydrogenase," "2019 novel coronavirus," "2019-nCoV," and "COVID-19". Articles which provide data about patients with COVID-19 whether of severity or not (including either respiratory distress, ICU admission, and/or death) were selected [1]. LDH elevations were reported based on reference laboratory parameters for each study. Two investigators (X.Y. Chen, M.Y. Huang) independently extracted the data by discussing with the corresponding authors about any different opinions until they reach a mutual agreement. We applied the exact binomial method to extract the odds ratios
(OR) in forest plots with 95\% confidence interval (CI). The presumption of homogeneity was not accepted as a valid statement when $P<0.1$ and $I^{2}>$ $50 \%$. All data were processed in the Stata version12.0 (StataCorp, College Station, TX).

After reviewing titles as well as abstracts, we continued to read the whole texts of the remaining articles. At last, a total of 6 articles were selected by this meta-analysis as shown in Table 1. Figure 1 summarizes the OR pooled by the selected studies, showing that elevated LDH values are related to an almost 12-times increase in the risks for severe COVID-19 with low heterogeneity being observed (OR, 12.43; 95\% CI, 7.23-21.38; $P<0.001 ; I^{2}, 8.2 \%$ ). Therefore, the fixed-effects model was used for the meta-analysis.

Findings of this meta-analysis suggest that measuring LDH might be helpful in predicting whether COVID-19 will evolve into a more severe state. This conclusion has its reasonable grounds. LDH, a cytoplasmatic enzyme, can be found in basically every main organ system. If cell lysis occurs, or cell membranes are damaged, LDH will be released into the extracellular space [2]. In acute inflammation, the changes in cells are manifested as neutrophils influx which may be the cause of the lung damages

\footnotetext{
*Correspondence: dryangxh@126.com; drchxq@163.com

1 Department of Respiratory Medicine, Fujian Medical University Union

Hospital, Fuzhou 350001, Fujian, People's Republic of China

Full list of author information is available at the end of the article
} 
Table 1 Characteristic of included studies ( $n$ no. of patients)

\begin{tabular}{llllllll}
\hline Study, year & Country & $\begin{array}{l}\text { Females, } \\
n(\%)\end{array}$ & $\begin{array}{l}\text { Median } \\
\text { age }\end{array}$ & $\begin{array}{l}\text { Total } \\
\text { patients }\end{array}$ & $\begin{array}{l}\text { Severe } \\
\text { patients, } n(\%)\end{array}$ & \multicolumn{2}{l}{$\begin{array}{l}\text { LDH (increased/total), } n(\%) \\
\text { Severe }\end{array}$} \\
\hline Huang, 2020 & China & $11(26.8 \%)$ & 49.0 & 41 & $13(31.7 \%)$ & $12 / 13(92.3 \%)$ & Non-severe \\
Wang, 2020 & China & $37(54.0 \%)$ & 42.0 & 69 & $14(20.3 \%)$ & $10 / 12(83.3 \%)$ & $15 / 49(30.6 \%)$ \\
Zhou, 2020 & China & $72(38.0 \%)$ & 56.0 & 191 & $54(28.3 \%)$ & $53 / 54(98.1 \%)$ & $70 / 130(53.8 \%)$ \\
Zhang, 2020 & China & $66(57.4 \%)$ & 49.5 & 115 & $31(30.0 \%)$ & $17 / 31(54.8 \%)$ & $9 / 84(10.7 \%)$ \\
Wan, 2020 & China & $63(46.7 \%)$ & 47.0 & 135 & $40(29.6 \%)$ & $30 / 40(75.0 \%)$ & $28 / 95(29.5 \%)$ \\
Chen, 2020 & China & $4(19.0 \%)$ & 56.0 & 21 & $11(52.4 \%)$ & $10 / 11(90.9 \%)$ & $1 / 10(10.0 \%)$ \\
\hline
\end{tabular}

occurred and the production of the toxicity of cells [3-5]. The cytotoxicity of neutrophils was suggested as being related to ARDS [6]. LDH elevations are related to the aforementioned cell damage or inflammation or both.

Our meta-analysis has a few limitations. All studies are from China. In order to exclude the influence of the genetic factor, data from other countries should be compared. Due to the nature of reporting in the emerging outbreak, we do not conduct a risk of bias assessment. Future analyses need to aim at confirming the results of this paper as well as pooling data to find other laboratory markers of severe COVID-19.

We confirm that LDH elevations are associated with increased risk for severe COVID-19. It can be used to provide predictions for the severe disease during hospitalization to guarantee proper clinical care for the patients.

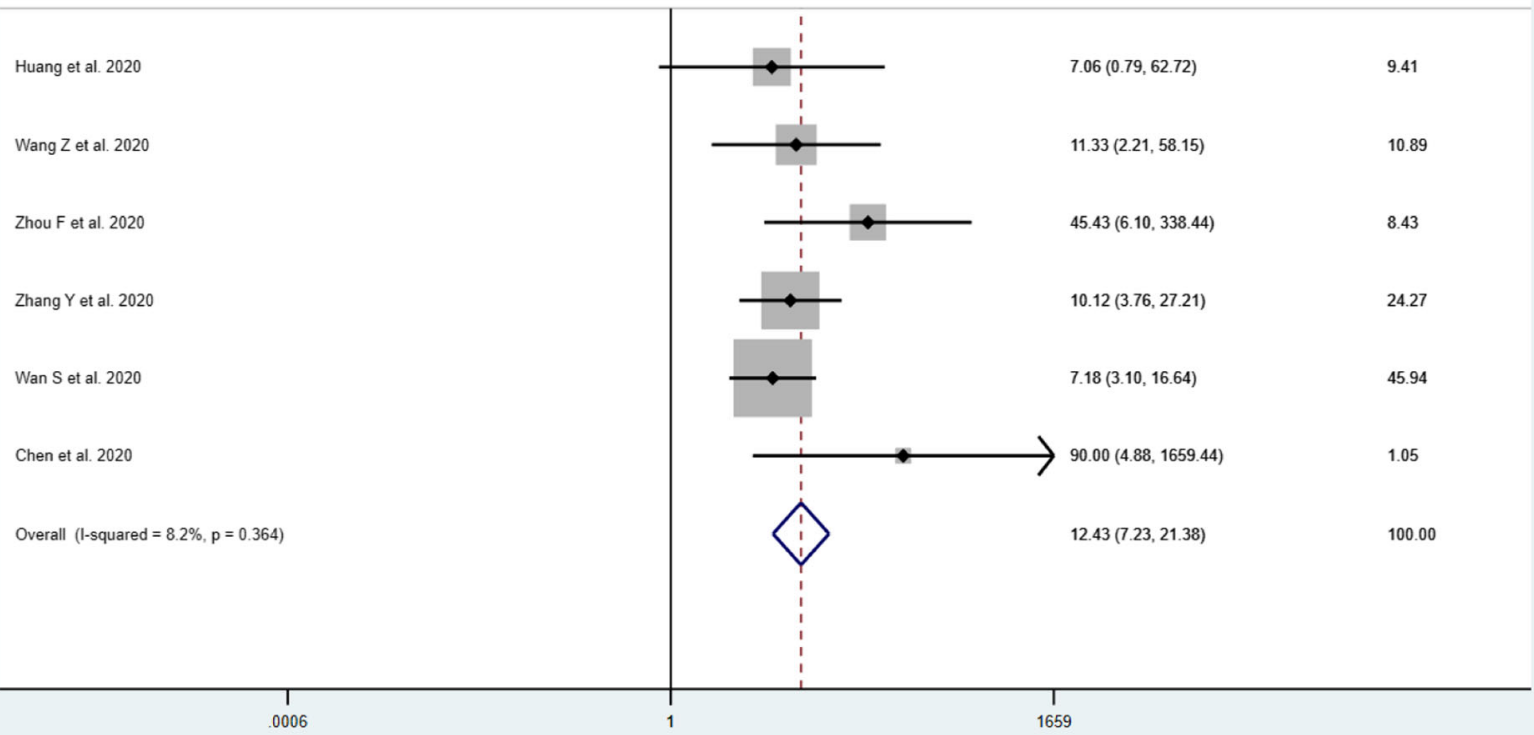

Fig. $1 \mathrm{OR}$ and $95 \% \mathrm{Cl}$ of LDH values beyond normal reference range for the prediction of severe COVID-19 


\section{Abbreviations}

LDH: Lactate dehydrogenase; COVID-19: Coronavirus disease 2019;

ICU: Intensive care unit; OR: Odds ratio; Cl: Confidence interval; $n$ : No. of patients; ARDS: Adult respiratory distress syndrome

\section{Acknowledgements}

None

\section{Authors' contributions}

Chen Xiaoyun designed the study and drafted the manuscript. Huang Mingyao contributed to the data collection and the analysis of the data. Xiao Zhengwei helped in data analysis. Chen Xiangqi and Yang Sheng revised the manuscript and approved the final version for publication. All authors have read and approved the final manuscript.

\section{Funding}

This work was supported by the Novel Coronavirus Pneumonia Emergency Project of Fujian Province(2020Y0006).

\section{Availability of data and materials}

The datasets used and/or analyzed during the current study are available from the corresponding author on reasonable request.

\section{Ethics approval and consent to participate}

Not obtained as this is a systematic review and meta-analysis of published studies.

\section{Consent for publication}

Not applicable.

\section{Competing interests}

The authors declare no competing/conflict of interest.

\section{Author details}

'Department of Respiratory Medicine, Fujian Medical University Union Hospital, Fuzhou 350001, Fujian, People's Republic of China. ${ }^{2}$ Department of General Surgery, The Fourth Affiliated Hospital, China Medical University, Shenyang 110000, People's Republic of China. ${ }^{3}$ Department of Orthopaedics, Fujian Provincial Hospital, Fuzhou 350001, Fujian, People's Republic of China.

Received: 30 June 2020 Accepted: 9 July 2020

Published online: 24 July 2020

\section{References}

1. Aziz M, Fatima R, Assaly R. Elevated interleukin-6 and severe COVID-19: A meta-analysis [published online ahead of print, 2020 Apr 28]. J Med Virol. 2020;10.1002/jmv.25948. https://doi.org/10.1002/jmv.25948.

2. Drent M, Cobben NA, Henderson RF, Wouters EF, van Dieijen-Visser M. Usefulness of lactate dehydrogenase and its isoenzymes as indicators of lung damage or inflammation. Eur Respir J. 1996:9(8):1736-42.

3. Lynch JR, Standiford TJ, Rolfe MW, Kunkel SL, Strieter RM. Neutrophilic alveolitis in idiopathic pulmonary fibrosis. The role of interleukin-8. Am Rev Respir Dis. 1992;145(6):1433-9.

4. Dunnill MS. Pulmonary fibrosis. HISTOPATHOLOGY. 1990;16(4):321-9.

5. Cherniack RM, Colby TV, Flint A, Thurlbeck WM, Waldron JJ, Ackerson L, Schwarz MI, King TJ. Correlation of structure and function in idiopathic pulmonary fibrosis. Am J Respir Crit Care Med. 1995;151(4):1180-8.

6. Henderson RF, Harkema JR, Hotchkiss JA, Boehme DS. Effect of blood leucocyte depletion on the inflammatory response of the lung to quartz. Toxicol Appl Pharmacol. 1991;109(1):127-36.

\section{Publisher's Note}

Springer Nature remains neutral with regard to jurisdictional claims in published maps and institutional affiliations.

Ready to submit your research? Choose BMC and benefit from:

- fast, convenient online submission

- thorough peer review by experienced researchers in your field

- rapid publication on acceptance

- support for research data, including large and complex data types

- gold Open Access which fosters wider collaboration and increased citations

- maximum visibility for your research: over $100 \mathrm{M}$ website views per year

At $\mathrm{BMC}$, research is always in progress.

Learn more biomedcentral.com/submissions 